\title{
On Food, Pots, Gender, Iron, and Archaeological Theory: Interview with Professor Randi Haaland
}

\author{
Lenka Varadzinová(D) - Marek Jakoubek (i)
}

Accepted: 4 November 2021 / Published online: 22 February 2022

(C) The Author(s), under exclusive licence to Springer Science+Business Media, LLC, part of Springer Nature 2022

\begin{abstract}
Professor Randi Haaland is a Norwegian archaeologist with a distinctive anthropological approach and global research interests. In this conversation, Randi Haaland reflects on her extraordinary and multifaceted engagement with archaeology and Africa for over 50 years, from her formative experience as a young woman among the Fur in Sudan in the mid-1960s, through her research between the processual and post-processual paradigms, to the capacity-building programs she initiated with the support of the Norwegian Agency for Development Cooperation (NORAD). Randi Haaland created her unique path in the archaeology of Africa. This interview shows that it has been the right path towards a novel and in-depth understanding of the human past, especially on food culture, beginnings of food production, gender, and technology.
\end{abstract}

Archaeological time period Holocene prehistory, historical period

Country and region discussed Africa, Southwest Asia, Indian subcontinent

L. Varadzinová $(\bowtie)$

Czech Institute of Egyptology, Faculty of Arts, Charles University, Celetná 20, 11000 Prague 1, Czech Republic e-mail: lenka.varadzinova@ff.cuni.cz

M. Jakoubek

Institute of Ethnology, Faculty of Arts, Charles University, Celetná 20, 11000 Prague 1, Czech Republic

e-mail: marek.jakoubek@ff.cuni.cz
Résumé La professeure Randi Haaland est une archéologue norvégienne réputée pour une approche antropologique distinctive et des intérêts de recherche mondiaux. Dans cette conversation, Randi Haaland réfléchit sur son engagement extraordinaire et multiforme avec l'archéologie et l'Afrique depuis plus de cinquante ans, à partir de son expérience formatrice d'une jeune femme parmi les Four au Soudan au milieu des années 1960, en passant par ses recherches entre les paradigmes processuel et post-processuel, jusqu'aux programmes de renforcement des capacités qu'elle a initiés avec le soutien de l'Agence norvégienne de coopération au développement (NORAD). Randi Haaland a créé sa voie unique dans l'archéologie de l'Afrique. Cet entretien montre qu'elle a été la bonne voie vers une compréhension nouvelle et approfondie du passé humain, en particulier sur la culture culinaire, les débuts de la production alimentaire, le genre et la technologie.

Keywords Gender · Food · Ceramics · Iron · Capacity building $\cdot$ Anthropology

\section{Introduction}

Randi Haaland (Håland) is a Norwegian Africanist archaeologist with global research interests (Fig. 1). In 1988 she was appointed Professor of African and Middle Eastern Archaeology at the University of Bergen. She retired from a formal academic appointment in 2011. 


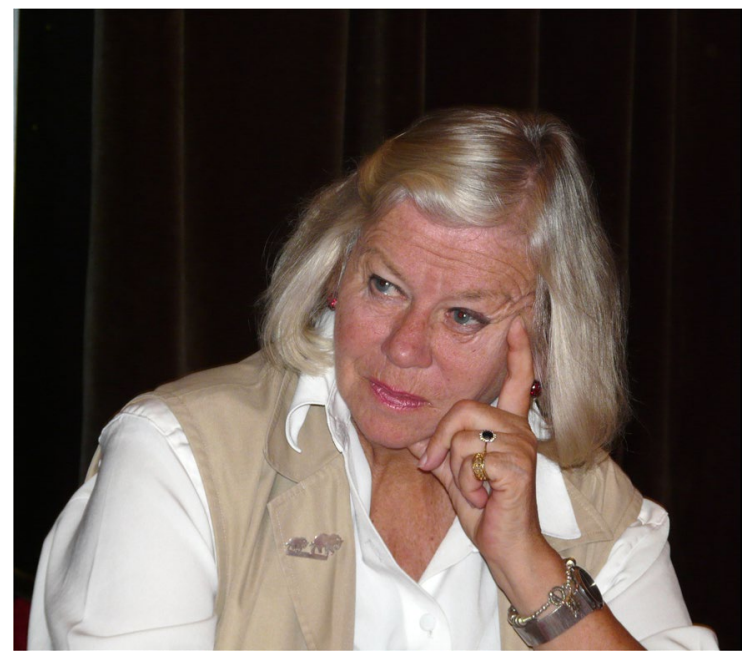

Fig. 1 Professor Randi Haaland at a seminar in Amman. Photo by Bert de Vries, 2008.

Professor Haaland has carried out archaeological and ethnographic fieldwork in Sudan, Mali, Ethiopia, Tanzania, Zimbabwe, Palestine, India, and Nepal. In her research, she focused on capacity building in the countries where she worked. She cooperated with the Khartoum, Dar es Salaam, and Addis Ababa universities to promote archaeology as an independent discipline and trained students from different countries in Africa and Asia for master's and doctoral degrees. These capacity-building efforts were undertaken with the support of the Norwegian Agency for Development Cooperation (NORAD), through its Program for Development, Research, and Education (NUFU). The program made it possible for students from ten African countries to complete their studies at the University of Bergen.

Professor Haaland has particularly explored the role of women in cultural-historical developments. Her curiosity and intuition led her to investigate a broad spectrum of topics, including early cultivation and domestication of plants, the emergence of pottery production, ironworking technology, and culinary practices. She has opened new levels of understanding the past by employing a long-term perspective in studying cultural evolution in the Nile Valley and pursuing supra-regional comparisons and exchanges between Africa and India and the Near East and Northeast Africa. Her early contact with the anthropological milieu at the University of Bergen endowed her research with a distinctive perspective that was further enriched by her ethnographic fieldwork and the anthropological work of her husband, Gunnar.

Professor Haaland has (co-)authored a great many thought-provoking works (see the "selected bibliography" below) in which she proposed courageous scenarios of developments for which "hard" evidence was yet to be brought to light and which later became an integral part of the archaeological discourse. In 2000, she was elected the first female president of the Society of Africanist Archaeologists. In 2006, Professor Haaland and her husband Gunnar received a prize for excellent research in comparative culturehistorical studies from the Institute of Comparative Research in Human Culture in Oslo. In 2008 she was awarded the Gold Medal of Merit by the Norwegian King for her significant academic contribution.

This interview builds on the lecture, "Mothers' milk, beer, and early pottery making: On the use of ethnographic observations for interpretation of the role of women in cultural-historical developments in Africa," that Professor Haaland delivered in Prague on December 5, 2019 (see Haaland, 2021). The event originated from the invitation extended by the Institute of Ethnology, the Institute of Classical Archaeology, and the Czech Institute of Egyptology of the Faculty of Arts, Charles University. The decision to conduct the interview followed soon after the lecture. The COVID-19 pandemic, however, made it impossible for the participants of the interview to meet in person. The interview was therefore conducted via e-mail. We prepared the initial set of questions and sent it to Professor Haaland in September 2020. She then used the same medium to return her answers. This process began a long chain of questions and answers via e-mail exchanges until the first draft was completed in June 2021.

\section{Study and Influences}

$L V$ and $M J$ : How did you become entangled with Africa?

$R H$ : My first interest in Africa started with Sudan. I joined my husband, Gunnar, for a year in Darfur in 1965-1966. He was an anthropologist who studied the Fur people. We had brought our two-year-old son with us. I then got fascinated by Sudan-Darfur and its people. I was at the time an undergraduate student at 
the University of Bergen with a background in anthropology and sociology. I was just an expatriate wife and did not have any research project, an ordinary woman who was curious about people's lives. In the villages, I became interested in the lives of women, particularly in their daily activities. I spent time walking around with our two-year-old son. The two of us became a familiar sight among the inhabitants. I would sit with women, participating in their daily activities and trying to grasp more or less intuitively something about their life. As I always had my son with me, the women likewise would have their children strapped to their back or be breastfeeding them. We would sit together for hours, and I would watch the women in different contexts - child-care, food preparation, cultivation, etc. My interest in women and gender studies started with my one year in Darfur. I was not involved in archaeology at that time.

I started my archaeological studies the year after I returned to Bergen. I first had to take a degree in Nordic archaeology. However, for my postgraduate studies, I was able to study the materials excavated by the Scandinavian Joint Expedition (SJE) to Sudanese Nubia in the framework of the UNESCO salvage campaign. I completed my Magistergrad (Master's degree) at the University of Bergen in 1971. I was told then that since my academic competence was based on Sudanese material, it would not be possible to get a job in Norway. I was offered a job at the University of Khartoum the year after, and the rest is history.

$L V$ and $M J$ : At that time, anthropology and sociology were represented in Bergen by Fredrik Barth and other leading figures, including your husband, Gunnar. How would you characterize anthropology in Bergen at that time? And how did this experience shape you as a researcher?

RH: Although I had studied anthropology and sociology, I did not consider anthropology an option since I did not want to be in the same department as my husband. I felt it was necessary for the two of us to have different backgrounds and disciplinary expertise. However, I found the anthropology milieu intellectually stimulating, especially when Fredrik Barth organized the international seminar on ethnic groups and boundaries. The seminar was published in 1969 as Ethnic Groups and Boundaries (Barth, 1969) and has become one of the most cited books in anthropology.
$L V$ and $M J$ : What made you shift from anthropology to archaeology?

$R H$ : I was concerned that the Anthropology Department was rather male-focused. The general sense was that the men should be promoted in their work; the women's role was mainly to support their spouse. I was even warned the first time I wanted to join my husband for his one-year fieldwork in Sudan. The anthropologists (all male) argued that this was not recommended since he would focus less on his fieldwork. However, both Gunnar and I felt it was too long for Gunnar to be separated from our son. Gunnar strongly supported my different choices, especially to join him in Darfur. We had one year together as a family in Darfur, and I think we both benefited from it, both academically and as a family (Fig. 2).

$L V$ and MJ: How would you characterize Norwegian archaeology at that time?

$R H$ : Studies in Bergen were limited to Nordic archaeology. I did my bachelor's degree in Nordic archaeology. The focus of teaching and research in the department was Nordic archaeology and Scandinavian archaeology at best. The practice and teaching of archaeology were quite nationalistic. Neither showed much interest in the cultural history outside northern Europe, even though two archaeologists had participated in the Scandinavian Joint Expedition to Sudanese Nubia in 1964-1965. The milieu was also influenced by the processual archaeology, which was quite local in its approach.

$L V$ and $M J$ : Who inspired or influenced your work in archaeology at the undergraduate and Magistergrad levels?

$R H$ : It is rather difficult to pinpoint. However, the first supervisor of my Magistergrad, Knut Odner, was important for the choices I made in archaeology. He had a broad and curiosity-driven approach to cultural history. Knut took part in the Scandinavian Joint Expedition's fieldwork in Nubia in 1964-1965. However, he did not work on this material after he came back to Bergen. His work included Stone Age and Iron Age sites in Norway, and later, in 1969, he took on a research position at the British Institute in Eastern Africa, in Kenya. He got involved both in ethnographic fieldwork and archaeological excavation during his one-year stay. He pursued varied topics such as rock-art research and problems related to understanding the links between archaeology and language, especially the Bantu languages. His research was a 
Fig. 2 Gunnar Haaland with their 2-year-old son outside their house in the Fur village of Tour in northwestern Darfur, Sudan. Photo by Randi Haaland, 1966.

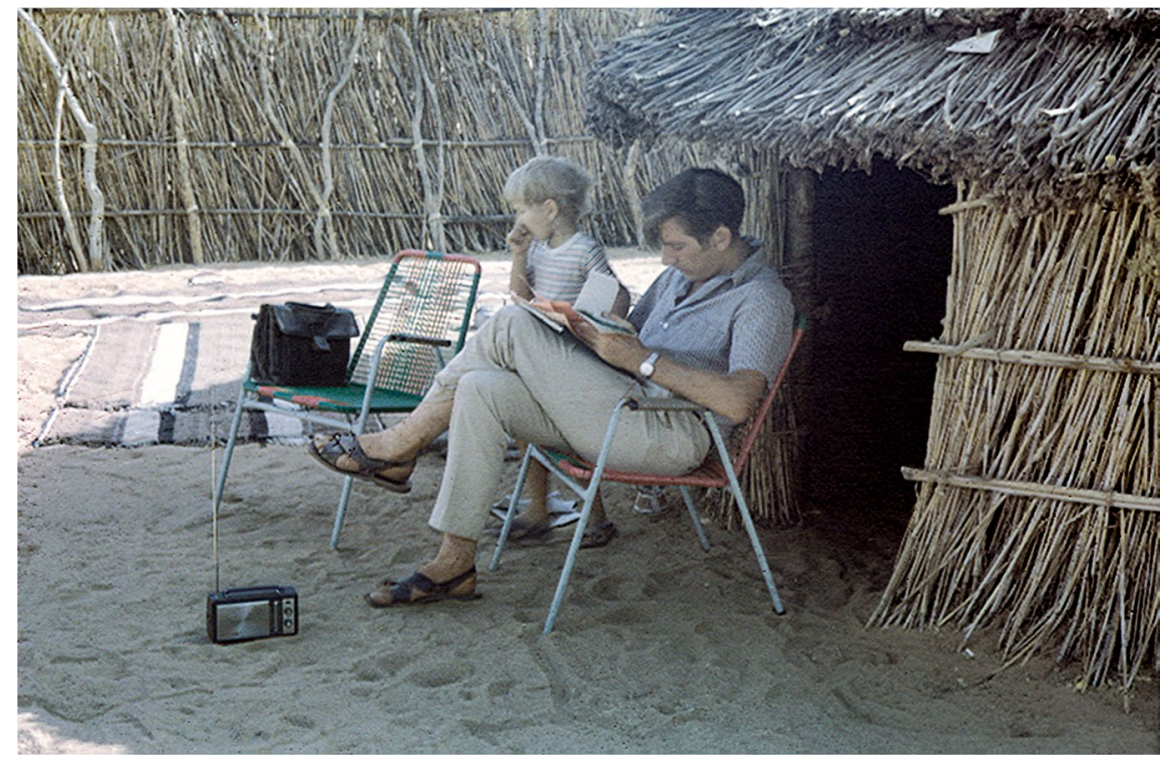

clear inspiration for the wide range of topics I have pursued. The tendency among Norwegian archaeologists was to study one region in detail over time. To some extent, I think this has also been the case with some archaeologists working in Sudan.

Bruce Trigger became very important for my work when I wrote my doctorate thesis. I met him at the first conference on the prehistory of Northeastern Africa in Dymaczewo, near Poznań in 1980 (see Krzyżaniak and Kobusiewicz, 1984). He was very open and generous in his discussions, especially with young archaeologists. He was the opponent (external reviewer) for my doctorate in 1982 and underlined what he saw as the contribution of my work to further research. Trigger always acted with dignity. His perspectives were based on thorough local knowledge and a global perspective. These local and global approaches influenced my work, from studying the Neolithic and Mesolithic sites along the Nile to widening my research scope to include North Africa, the Near East, and the Indian subcontinent.

LV and MJ: In 1972, one year after your graduation, you accepted a lecturer position in the Department of Archaeology at the University of Khartoum. How would you characterize the situation in Khartoum and Sudan at that time?

$R H$ : My employment at the University of Khartoum in 1972-1974 shaped my academic career and the later development of cooperation between archaeology departments at the University of Khartoum and the University of Bergen. This resulted in a signed agreement between the two universities in 1984, a partnership first initiated by Fredrik Barth and my husband Gunnar in anthropology. It is important to look at the background of archaeological studies at the University of Khartoum. Peter Shinnie had played a crucial role in establishing a department of archaeology at the university. His academic background was from Oxford, and he had previously been the Commissioner for Archaeology at the Sudan National Museum, where he took over from Anthony John Arkell. However, before taking the professorship at the University of Khartoum in 1966, he taught at the University of Ghana for four years. Interestingly, he had also organized an archaeological team from the University of Ghana to work at Debeira West in Sudanese Nubia in 1961-1964 in the framework of the UNESCO-organized salvage campaign (Shinnie and Shinnie, 1978). Shinnie had a wide fieldwork experience, having also worked at Meroe for 11 years. With his solid background in classical studies, he always tried to place local site inventories in wider global contexts.

I did not experience more difficulties being a woman in Sudan than I experienced in Norway. It was rather being Norwegian, which made it difficult. At the time, Sudan was still experiencing the influence of being a condominium of Britain and Egypt between 1899 and 1955. Like other colonial powers, Britain had built up a strong archaeological and 
anthropological competence in museums and university departments. Many wondered why I, coming from a country with hardly any tradition of African archaeology, was hired instead of a British or American archaeologist for the position of a lecturer in the Archaeology Department. It was quite obvious that English academics in Sudan had a much higher standing than Norwegians. The influence of the British was strong and still is today. I should add that my husband, a lecturer in anthropology at the University of Khartoum during the same time (1972-1973), had fewer problems being Norwegian. It probably helped that Fredrik Barth had been teaching in the Department of Anthropology the year before. He already had a name in anthropology and thus paved the way for Gunnar. During this time, Jaafar Nimeiry was the president (ruled, 1969-1985); the political situation was unstable, and there were many attempted coups. Different political factions such as the communists and Muslim Brotherhood competed for power. This was before Nimeiry introduced Sharia. So, the relations between male and female students were open and relaxed. In seminars, female students participated and were quite outspoken, freely expressing their points of view.

\section{Fieldwork}

LV and MJ: Between the 1970s and 1990s, you conducted diverse field research in Sudan, concerned with both archaeology and anthropology. How did you choose sites for fieldwork, and what were the questions you were addressing?

$R H$ : The Polish archaeological team at Kadero played an invaluable role in my involvement in Sudanese archaeology. Kadero, situated some $30 \mathrm{~km}$ north of Khartoum, would become one of the most wellknown sites of the so-called Khartoum Neolithic in sub-Saharan Africa. At that time, Lech Krzyżaniak was in charge of the excavation. Lech Krzyżaniak kindly allowed me to use part of the excavated materials for my Ph.D. thesis. This cooperation was the basis of my interest in the Neolithic period. The material inventory of the Kadero site indicated that the people exploited different resources. They engaged in animal husbandry but also utilized plant foods, wild animals, and aquatic resources. Kadero dated to the fifth millennium $\mathrm{BC}$, and it is one of the first sites excavated in sub-Saharan Africa with evidence of domestic animals. Cattle were especially numerous. The most frequent types of archaeological material were ceramics and fragments of grinding stones. These are the similar materials that I observed during my previous stay in Darfur, which relate to women's activities. The Neolithic material fascinated me.

After three years, having completed my contract with the University of Khartoum, I went back to Norway. I applied for funds from the Norwegian Research Council to survey and excavate sites in different micro-environmental zones close to Kadero. I was lucky enough to get a five-year research grant. The project was in cooperation with two of my former BA students. During the period 1978-1979, we excavated the Neolithic sites of Zakiab and Um Direiwa. These sites were selected to get an understanding of the yearly cycle of adaptation. Both Ali Tigani el-Mahi and Anwar Abdel-Magid Osman, who engaged with me in this project, were later supported by the Norwegian Agency for Development Cooperation (NORAD) to complete their doctorates at the University of Bergen. While Kadero was a base site and ritual center occupied year-round, Zakiab and Um Direiwa were seasonal sites. Pottery and grinding stone fragments abounded on these sites. To get a better understanding of the technology and social context of these finds, I did three separate ethnographic fieldworks in Darfur, in which I focused on the study of these materials and women's work in agricultural production (Fig. 3), food preparation, and the rearing of children (Fig. 4). This was the beginning of my gender studies.

As regards the archaeological materials, the lack of domestic plants in the Khartoum Neolithic puzzled me since the sites have the hallmark of agricultural communities, i.e., cultivation. However, we recovered imprints of plants in pottery, such as sorghum and millets, but these imprints showed no genetic changes to indicate they were domesticated. Still, based on the large size of the sites and the number of grinders and pottery, I argued that the people most likely cultivated these cereals. Using my anthropological background, I argued that the domestication of cereals must have been preceded by a long period of cultivation. This was based on the theoretical assumption that domesticated varieties could only have emerged as a consequence of farming practices, such as sowing, weeding, and harvesting. These would have acted as selection pressures on the wild plant population. 
Fig. 3 Women selling local vegetable products at the market in Zalingei, western Darfur. Photo by Randi Haaland, 1973.

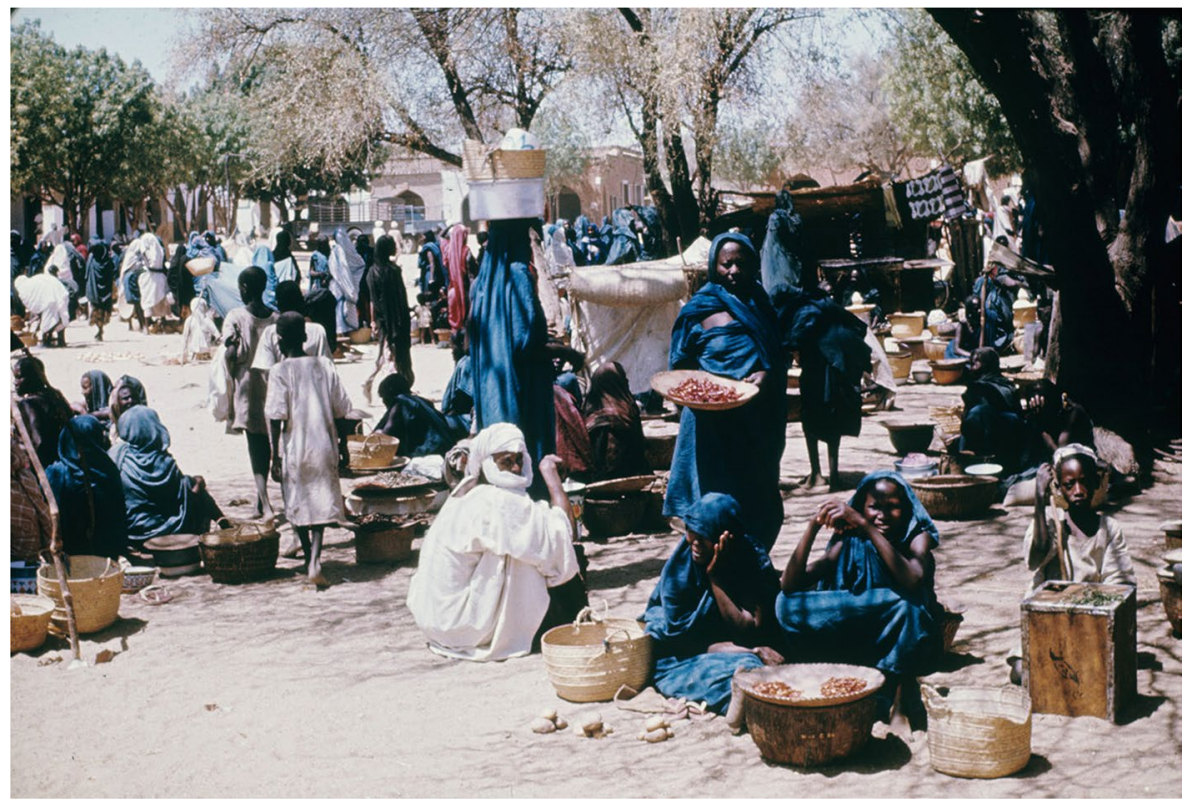

In other words, the socio-economic process of wild plant cultivation must have preceded the biological process of domestication. When I presented this argument at the first Dymaczewo conference in 1980, my perspective was strongly criticized. Today, this idea is widely accepted (e.g., Fuller, 2007; Fuller et al., 2014, 2016, 2018). I am discussing this in more detail here because of the severe manner this idea was criticized when I first proposed it. I was at the beginning of my career, and it was a difficult experience. My advice to colleagues is always to engage in open and positive discussions in order to allow new ideas and perspectives to develop.

Along the way, I became fascinated with the gaps in our knowledge on how African sorghum was domesticated. It seems to have been domesticated late, with the domesticated form present quite early on the Indian subcontinent. This was the background for my later fieldwork in the Deccan Plateau in India, with savannah vegetation similar to the African savannah. It was also the basis of my ethnographic work with Nepalese students in the hilly regions of Nepal, where people speaking Tibeto-Burmese languages were cultivating African-type sorghum and millets (Haaland, 2011). I wanted to get an understanding of what I saw as the sorghum puzzle (Haaland, 1999). I concluded that sorghum was domesticated earlier in Africa than in India. However, it was introduced rather early to the Indian subcontinent. I emphasized

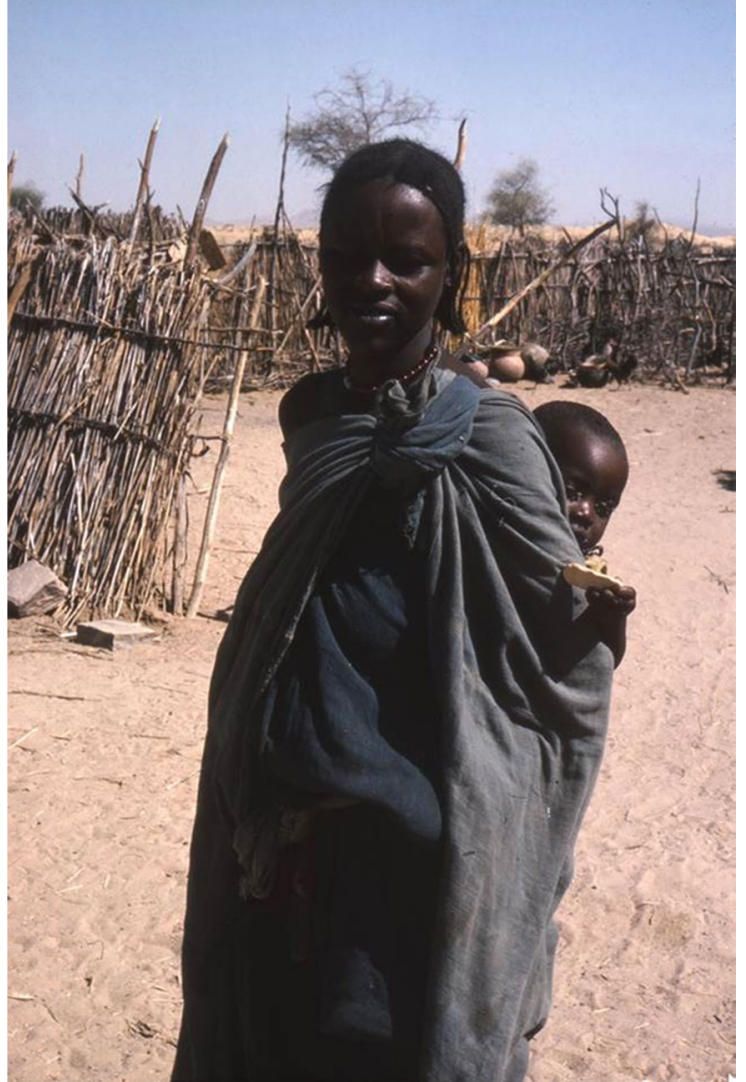

Fig. 4 Young Fur mother with her baby in Kuttum, northern Darfur. Photo by Randi Haaland, 1978. 
the importance of the sea route for this distribution. This scenario was already discussed by Carl O. Sauer (1952). I also attributed the early spread of sorghum from Africa to India to the maritime trade stimulated by the Indus Valley civilization (see Winchell et al., 2018 for a recent discussion).

My fascination with women's work and pottery brought me to investigate sites with remains of pottery older than that recovered at the Khartoum Neolithic sites (see Arkell, 1949; Caneva, 1983). The Atbara region further north seemed important, especially because several sites with remains of ceramics dated to the tenth-millennium BP had been found in the Central and Eastern Sahara (Close, 1995; see Jesse, 2010 for a more recent overview). Thus, from 1983 to 1990 , I excavated three sites situated near the junction of Atbara and the Nile in central Sudan, in cooperation with two Sudanese archaeologists and my former BA students: Ali Tigani el-Mahi and Anwar Abdel-Magid Osman (Fig. 5). Ali had completed his doctorate in osteology and archaeology at the University of Bergen in 1982 and was a new lecturer in the Department of Archaeology, University of Khartoum. Anwar was starting his degree in archaeology and botany. He later completed his doctorate in Bergen in 1988 and also joined the Archaeology Department in Khartoum.

We excavated three sites: Abu Darbein, ed-Damer, and Aneib, all located on the old riverbanks of the
Atbara and the Nile and ranging in size from 6,000 to $10,000 \mathrm{~m}^{2}$. The archaeological materials from the sites dated to the mid-ninth millennium $\mathrm{BC}$ and most dates clustered around 8000 BC. The work yielded some very interesting materials of the socalled Khartoum Mesolithic type. Most importantly, huge amounts of pottery were found, with the oldest dating back to the ninth millennium BC. These sites are possibly the 'forerunners' of the Khartoum Neolithic sites. The Khartoum Mesolithic inhabitants seemed to have been sedentary and exploited many resources, but they relied on the rich aquatic materials of the area. The dominant pottery is the so-called dotted wavy-line type, which had a wide distribution over the southern part of the Sahara and the Sahel and, somewhat later, along the Nile Valley. I was interested in understanding the innovation of pottery production. The material suggested that the invention of pottery took place as early as the ninth millennium $\mathrm{BC}$ somewhere in the zone that is today the southern Sahara and the Sahel. The evidence at Ounjougou in Mali has since pushed the emergence of pottery in Africa to the tenth millennium BC (Huysecom, 2020; Huysecom et al., 2009). These show that the African pottery was older than the inception of pottery in the Near East (e.g., Garfinkel, 1999; Moore, 1995). I suggested that the development of pottery took place in a context of emerging sedentism largely made possible by the development of techniques for exploiting more
Fig. 5 Randi Haaland with her former BA studentsAli Tigani el-Mahi (left) and Anwar Abdel-Magid Osman (center)—having a break during their fieldwork between Jebel Tomat and Rabak along the White Nile. Photo 1983.

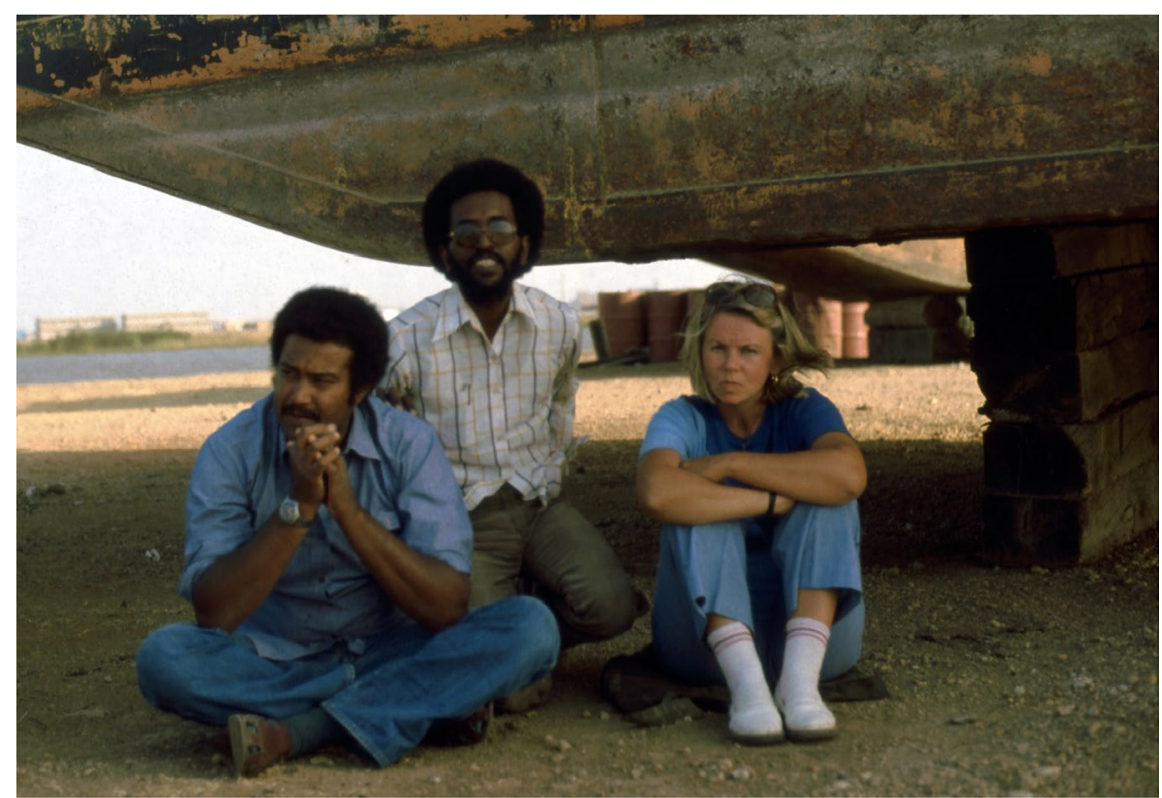


stable plant and aquatic resources (Haaland, 1995). I also argued that the invention of pottery made a fundamental difference in people's life experiences. The centrality of the woman's role as a nurturer is important to note here, from breastfeeding a child to feeding a household with boiled food, such as porridge and beer from the pots made by women. Thus, I suggested a deeply rooted connection between the pot, women, and nurturing, where the women transformed food from a natural to a cultural product. The pot is crucial in this transformation. A fundamental aspect of being a woman is her role as a nurturer (Haaland, 1997). From an evolutionary perspective, there appears to be a close interdependence between female-organized activities and some of the most important social developments like cultivation, the emergence of domesticated plants, pottery making, cooking, and increased sedentism.

$L V$ and $M J$ : Apart from Sudan, you worked in other countries in Africa and Asia. Is there something that connects your research in Sudan and those other places?

$R H$ : Working on the problems related to innovation and distribution of early pottery, I realized that pottery in the Levant and the Near East occurred quite late, around 2,000 years later than in what is today the southern Sahara and the Sahel region. It did not appear related to early agriculture. I was puzzled by this, and when I later participated in a large interdisciplinary project in Palestine-Jordan, I wanted to work on the differences in the food system between the two regions. I realized that the foodways of the Near East were based on bread and oven technology which could be traced back to the Early Neolithic, 10,000 years ago. In contrast, the African food systems, based on pottery and boiled food, have equally long antiquity. These two food systems were fundamentally different both in technology and symbolism. I have already mentioned above how I followed the dispersal of African plants like sorghum to the Indian subcontinent. Much of my work derived from this curiosity-driven research. My research in the Near East (especially Levant) made me understand how I could use archaeology, ethnography, and written historical sources for wide cultural-historical interpretations. It was quite fascinating; however, it was also very challenging, especially to use written sources since this was quite a new territory for me. Working on the food systems in the Near East also widened my horizon to include the Indus Valley and the Indian subcontinent.

Later I also worked with materials along the Nile dated to the Meroitic period, i.e., between the third century BC and the mid-fourth century AD. I discovered the interesting trade and cultural relations that had existed between the Indian subcontinent and Africa. I saw these expressed in cultural manifestations during the Meroitic civilization, often displayed in religious contexts, particularly in the architecture and decoration of temples. Similarities between the two continents were expressed in features such as the Elephant and the Lion gods. I discussed the possibility that some of these new elements were related to interactions across the Indian Ocean involving trade, migrations of craft specialists, and exchanges of ideas. Inge Hoffman, an Austrian archaeologist, wrote a book and several articles discussing the similarity in many features, especially emphasizing elephants. She published these in the early 1970s (e.g., Hoffman 1975). Unfortunately, she was heavily criticized by colleagues, and she did not follow up on the theme.

My work on Meroe was published in 2014 in African Archaeological Review, where I edited a special volume on Africa and the Indian Ocean (Haaland, 2014a, b). I also faced challenges in the Meroitic research. It took many years to get the article published. My experience was that the reviewers focused on their special expertise and skills, either in Africa or India, and could not understand the cross-cultural argument I was making. This complicated the whole publication process for my article and others in the special issue on the relationship between Africa and the Indian subcontinent. The experience reinforced the importance of having both local and wide global knowledge.

My research in Tanzania started in the 1980s. The archaeology unit in Dar es Salaam had approached NORAD to get support for teaching and training students. The agency wanted me to be involved. I saw this as an opportunity for capacity building and to do some work related to ironworking. Here, I could follow up on my ethnographic work on traditional ironworking in Darfur in 1973 and 1978. Some very interesting research was going on in Tanzania on this topic. I became involved in the excavation of the Early Iron Age site of Dakawa in east-central Tanzania dated to the late first millennium AD. I also conducted ethnographic fieldwork on traditional ironworking in Zumbawanga in western Tanzania. I took 
Fig. 6 Randi Haaland with her husband Gunnar and their two sons at an old English resthouse during a fieldwork break, Suni village, Darfur. Photo by Musa Adam Abduljalil, 1973.

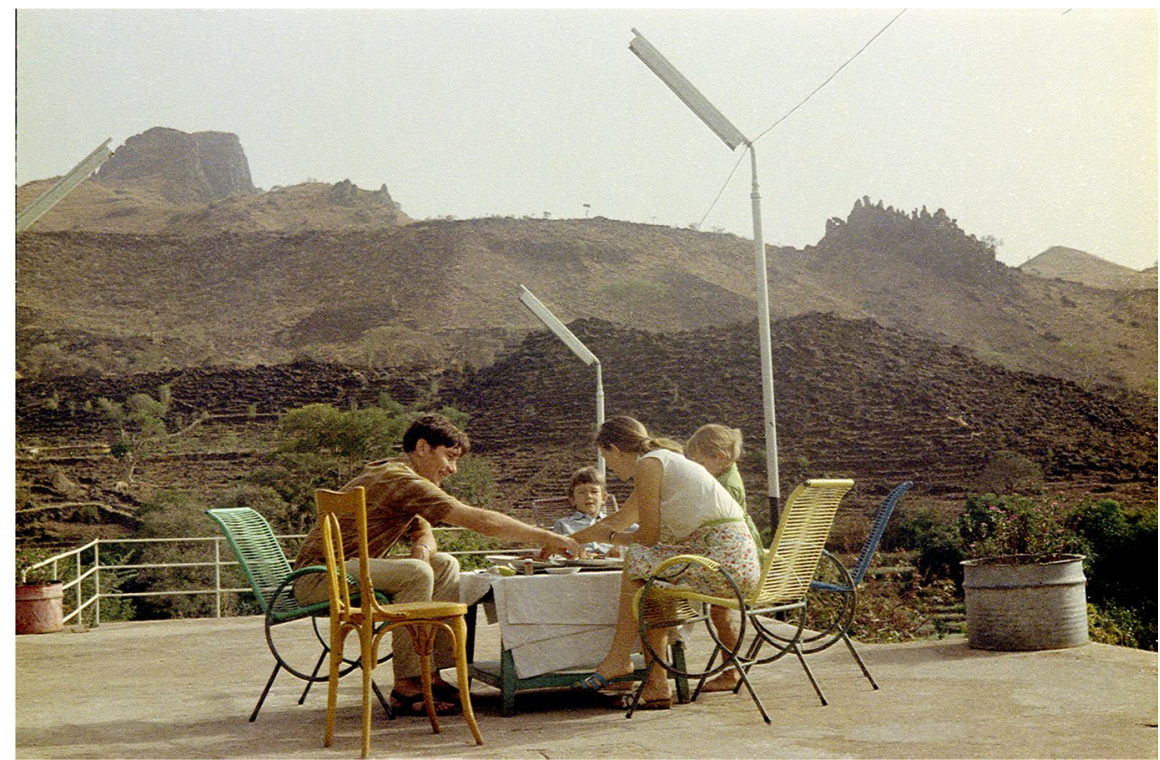

on two students to be part of the project. Later they received NORAD stipends and completed their master's degree in Bergen based on their fieldwork.

My interest in African ironworking also brought me to Ethiopia in the early 2000s in cooperation with Gunnar. We carried out fieldwork in a remote area north of the Omo Valley in southwestern Ethiopia, where smiths still practiced ironworking based on the traditional iron ore smelting. Later on, in 2004, I was asked to teach archaeology at Addis Ababa University, where archaeologists wanted to promote archaeology separately from history. At Addis Ababa, just as in many universities in Africa, archaeology was then part of the history department. After completing my teaching contract at Addis Ababa University, I supervised three students for a master's degree in Bergen, and one went on to the doctorate level. My attitude has always been that it is important to take on the training of students since we have the good opportunity to do fieldwork and thus have an academic career based on the permits for work in these countries - in my case, mostly in Africa. The last project of the Norwegian Development Agency (NORAD) and their Program for Development, Research, and Education (NUFU) that I took on for capacity building was in Zimbabwe, where I trained four students for their master's degrees. This time, I did not do my own research but engaged as a project manager participating in the fieldwork the students did in eastern
Zimbabwe on rock art. I saw the importance here to support archaeology as a discipline, which was being strained by very difficult political circumstances. All my students, except one, continued to work in Zimbabwe.

$L V$ and $M J$ : Two papers published in high-ranking journals have recently focused on the challenges researcher-parents working abroad face regarding raising a family and conducting fieldwork with their children (Lynn et al., 2018; Sohn, 2019). How did you combine your motherhood role with your position as a researcher, and how did you cope with the challenges this brought? Did you get any institutional support (grant, funds) as a researcher-parent? What would you recommend to researcher-parents heading to the field today?

$R H$ : In my experience, there was no institutional support for parents with children working in the field. What has worried me is that some universities even have policies that discourage women from marrying and having children. Some institutions make it clear that doing so would harm their career. So, many archaeologists who are parents of young children depend on family members, especially their parents and grandparents, to help out. Since the competition for research grants is getting more severe, there is little incentive to take on this fight. Even for Scandinavian archaeologists with long maternity leave, one year for women, and well-developed facilities with 
kindergartens, one still faces problems of being away from the children since most fieldwork is in distant places (Fig. 6).

\section{Methodology}

$L V$ and MJ: Anyone who reads your papers and books would notice two main elements of your research methodology: ethnography and a deductive approach. Could you specify your methodology and disclose the sources, influences, and inspirations you drew on?

$R H$ : This is a difficult question. In my research, I usually seek to establish arguments about processes that shape the form and distribution of objects prehistoric people left behind. This involves many methodological approaches. Ethnographic studies show a wide variety of factors that might have affected these processes, but ethnographic case-studies cannot serve as analogies for the unobservable processes in the past. They may, however, stimulate plausible and falsifiable hypotheses. I try to confront such hypotheses with reasoning from various fairly well-established approaches in ecological and socio-cultural disciplines. In many ways, I am clearly stimulated by Popper's philosophy (e.g., Popper, 1972), Barth's generative models (Barth, 1966), and Trigger's archaeological studies (Trigger, 1965, 1989).

$L V$ and $M J$ : Could you be more specific?

$R H$ : Fredrik Barth's processual analysis of forms of social life strongly influenced my interpretation of the distribution of archaeological material in time and space (Barth, 1966). How Bruce Trigger (1965) surveyed the settlement pattern of Lower Nubia and saw it as influenced by local environmental and external factors was important for my approach to interpreting the sites I excavated in the Middle Nile Region. Likewise, his History of Archaeological Thought influenced how I changed my perspective of material life through time (Trigger, 1989). And, Karl Popper influenced my criteria for establishing scientific statements: "In so far as a scientific statement speaks about reality, it must be falsifiable; and in so far as it is not falsifiable, it does not speak about reality" (Popper, 1972, p. 72).

$L V$ and $M J$ : In your career, you have experienced the heydays of both processual and post-processual archaeology, both of which formulated their major premises based on ethnography. How do you reflect these paradigms in your past and today's research?

$R H$ : As I mentioned above, the milieu in Bergen was heavily influenced by processual archaeology. The editorial staff of the Norwegian Archaeological Review was based in Bergen, and the journal was to become an important reference point for a discussion on processual archaeology in Europe. In my early academic phase, I was influenced by processual archaeology both in my archaeological and ethnographic fieldwork. I wrote my Magistergrad thesis based on the lithic material excavated by the Scandinavian Joint Expedition in Sudanese Nubia. When I started working on the lithic material in 1968, I was young and inexperienced. I was thus asked to use Fred Wendorf's classification system, which he had developed in his two volumes, The Prehistory of Nubia (Wendorf et al., 1968). Using similar criteria for classification made my work comparable to the work done by the Combined Prehistoric Expedition headed by Fred Wendorf. The processual approach dominated Wendorf's team's archaeology with its emphasis on counting and measuring 'objective' features of artifacts. Wendorf recorded in detail the statistical frequencies of tool types and the statistical differences of lithic material between the sites. He interpreted these as evidence of differences in ethnicity. However, I was critical of this interpretation as I had an undergraduate degree in anthropology and was influenced by the social anthropological perspective that Fredrik Barth and my husband Gunnar had on ethnicity. Barth saw ethnicity as a process of social interaction manifested in material culture, most often expressed in arbitrary, not functional features. My husband was part of Barth's research team working on this theme, and this team's work influenced my interpretation of ethnicity. I argued that ethnicity could not be discussed based on statistical differences evaluated by chi-square tests but on arbitrary differences or traits that prehistoric people had chosen to signal identities. My work was printed as a chapter in the volume on Neolithic and A-Group sites, published by the Scandinavian Joint Expedition to Sudanese Nubia and edited by HansÅke Nordström (Nordström, 1972). Later it was published as an article in the Norwegian Archaeological Review, where my perspectives created quite a lively discussion (Haaland, 1977; see Clark, 1977; Trigger, 1977; Wendorf et al., 1977). 

Fata Borno with the main pot maker. Photo by a villager, 1978
Fig. 7 Randi Haaland in

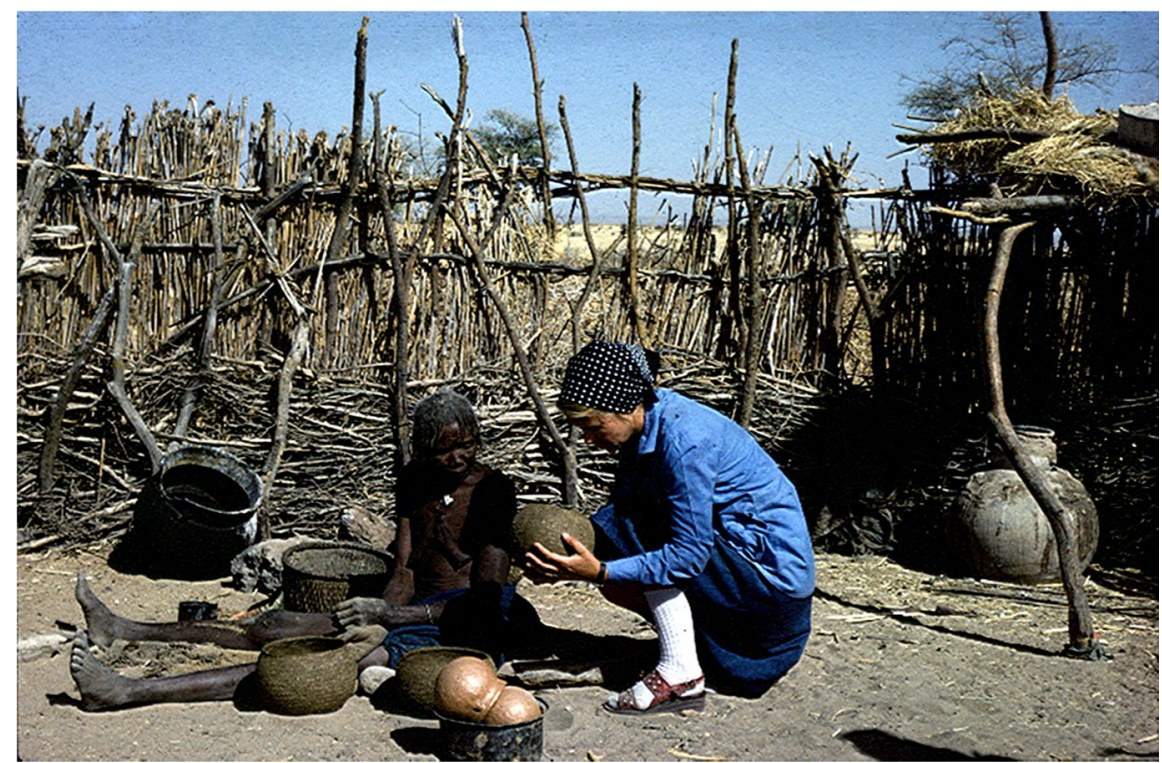

Fig. 8 Fur blacksmiths, starting to blow the bellows during the early part of iron-smelting. Photo by Randi Haaland, 1973.

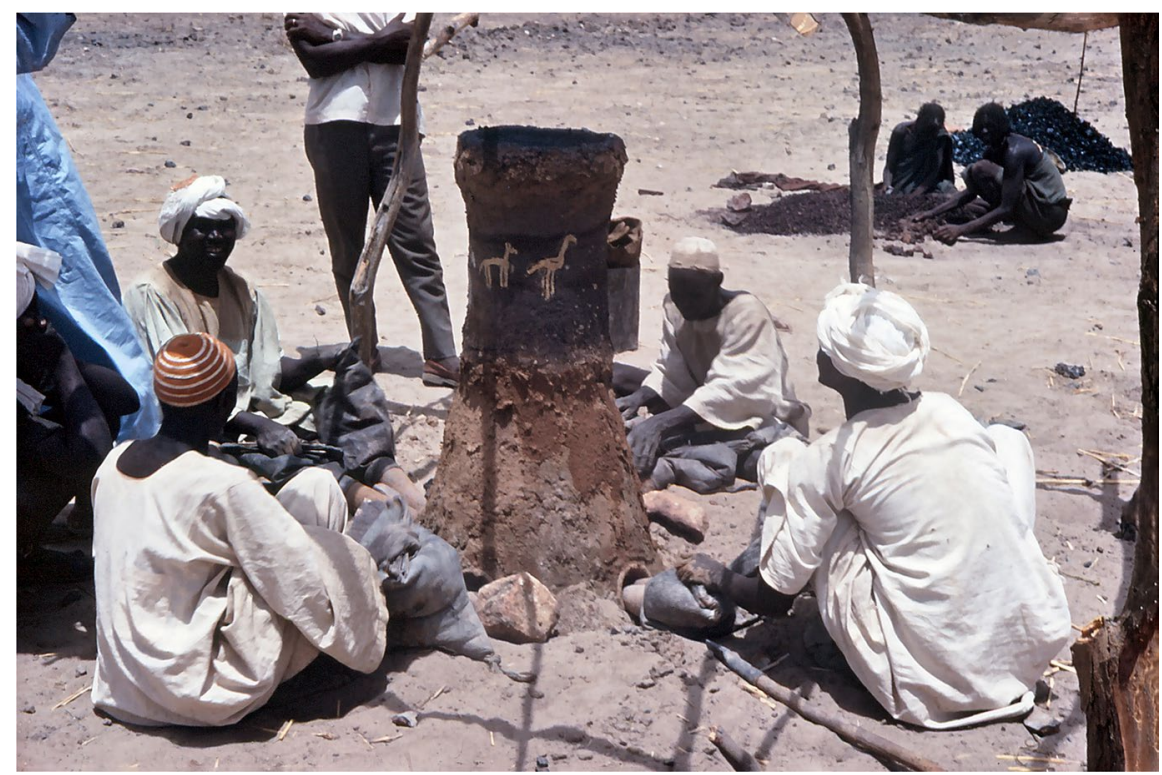

When excavating the Khartoum Neolithic sites in the late 1970s, my approach was processual in classifying the material. I counted and measured the excavated lithic materials quite rigorously. For example, I documented more than 30,000 grinding stone fragments at one site and classified them into upper and lower grinders. The main aim was to get an understanding of the technology and function of the artifacts. This approach was relevant to understanding other types of artifacts, such as pottery. The ethnographic work I did in Darfur on the production and use of pottery and grinding stones was also based on technological and functional perspectives (Fig. 7). However, and most importantly, I linked all of these to the broader framework of gender/female work.

During my first fieldwork in Darfur in 1973, both my husband and I were able to do an additional ethnographic study of traditional iron-smelting among the Fur, focusing on the technological and functional aspects (Fig. 8). Looking back, I regret that we did 
Fig. 9 Randi and Gunnar Haaland with Data Dea, Gunnar's doctorate student (to the left), and Wandemo, a schoolteacher in Uska Dencha, southwestern Ethiopia (to the right). Photo by a villager, 2003.
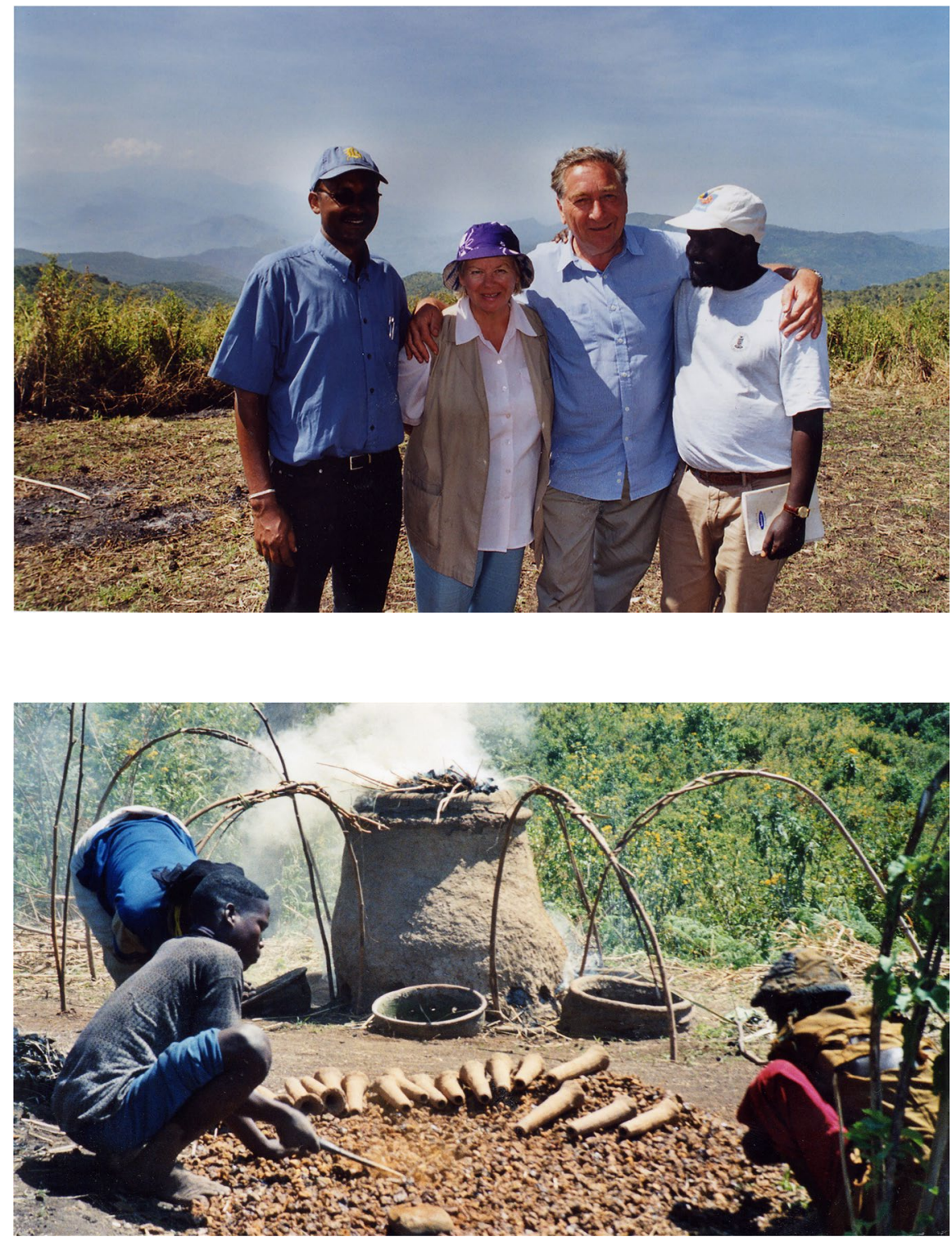

Fig. 10 The blacksmith has lit the furnace and is ready for smelting, Uska Dencha, southwestern Ethiopia. Photo by Randi Haaland, 2003. not focus on the symbolism of iron-smelting. Nevertheless, we recorded some of the ritual aspects, including songs, associated with this technology during our joint 1973 fieldwork and my own research in 1978.

My change in focus to post-processual archaeology was due to many factors, but one meeting at the PanAfrican Archaeological Congress in Nairobi in 1977 was crucial. Ian Hodder presented a paper on his ethnographic work in Sudan at the conference (Hodder, 1980). This paper was the basis for his book, Symbols in Action (Hodder, 1982). The book, in many ways, changed my perspectives. It felt like a new type of freedom. Previously one would not be taken seriously as an archaeologist if one discussed symbols. However, my approach to archaeology was also very much influenced by my husband's anthropological work.

$L V$ and $M J$ : You regularly went to the field with your husband Gunnar. How did you influence one another? Did you cooperate as researchers? Did you discuss your respective fields/topics?

$R H$ : Our first formal fieldwork together was among the Fur in 1972-1973. As I mentioned earlier, it was mainly related to the study of traditional ironworking. We also did fieldwork together in Ethiopia on 
Fig. 11 Two Fur women from the dry savannah landscape in northern Darfur fetching water. Photo by Randi Haaland, 1973.

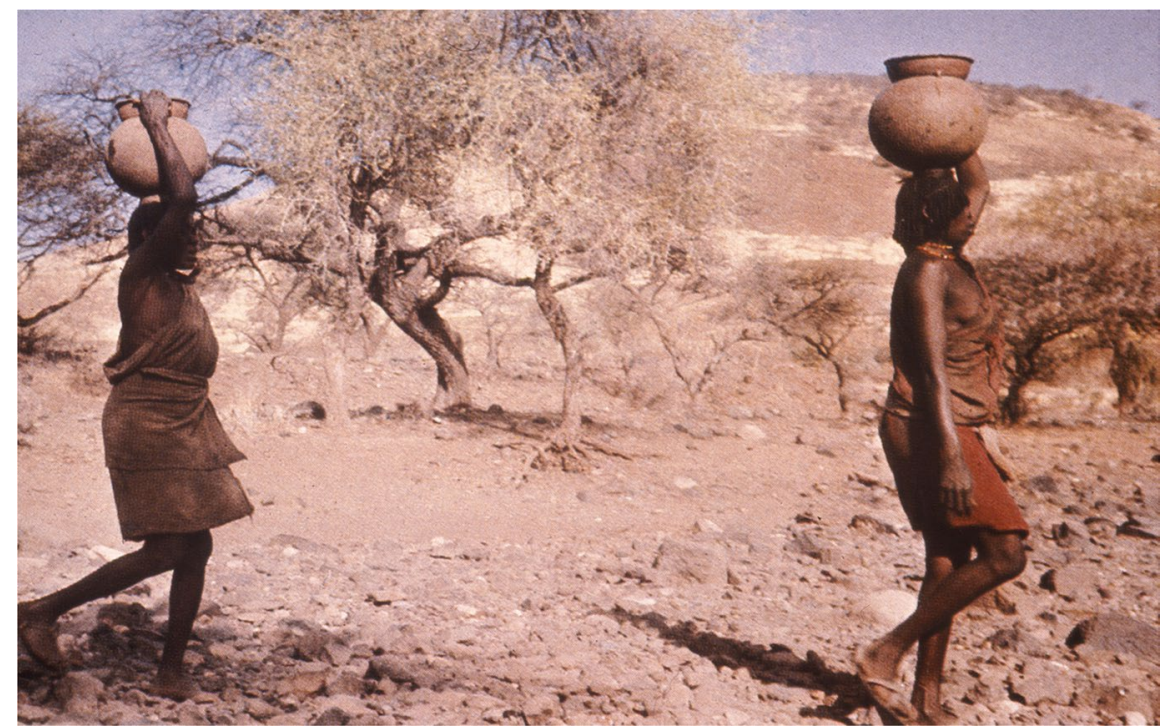

traditional iron-smelting. We were fascinated by African iron technology. Over time we realized the importance of the rich symbolic world surrounding iron-smelting. In 2001 we applied for money to do field research in the Omo Valley in southwestern Ethiopia. Gunnar was at the time working in the region with a doctoral student (Fig. 9). He received the information that traditional iron-smelting was still being practiced in Uska Dencha, a remote village in a hilly area whose link with outside communities consisted mainly of exchanging local wild coffee for salt. Smelting was still practiced because the village was quite inaccessible; it was not even recorded on the map. After five days of traveling, we were able to locate the place.

We succeeded in documenting the processes of smelting technology and the rich symbolism associated with the process, from quarrying the ore to smelting activities and harvesting the iron bloom from the furnace (Fig. 10). It was fascinating to experience the symbolism of smelting activities, a product of a long history that might go back to the Early Iron Age. Gunnar and I wrote several articles together on this subject. Later, the Norwegian Broadcasting Cooperation (NRK) made a film on the process of smelting in Uska Dencha. The film was presented on Norwegian television during Christmas in 2004. Another collaborative project was a general book we wrote together in 1982 on World Prehistory, In the beginning: From the first humans to the first civilizations, in Norwegian.
This cooperation was important because it allowed us to use our anthropological and archaeological perspectives in writing world prehistory. This was quite a comprehensive project with an emphasis on global cultural history and less on Europe.

Most of my work and writings on gender were influenced by Gunnar's study of the Fur people and his perspective on mother's milk (bora fatta) and beer and how this was selected as a convincing metonym for mother-child solidarity (e.g., G. Haaland 1990, 1998). He saw the repeated use of mother-child imagery in a wider range of social relations, sometimes as a tool of reassurance in precarious situations (e.g., May I trust your solidarity like I trust the solidarity of my mother?). This perspective became very important for my work on the importance of women and the female symbolism used in cultural history. In the process of writing my articles, I would always discuss with Gunnar to get his feedback. This was crucial for developing my social perspectives on the material. He always encouraged me to emphasize the female perspective.

$L V$ and $M J$ : Did the fact that you came to Sudan as a young woman and a mother influence your research topics? Did you learn anything important from this experience?

RH: Yes, my stay in Darfur for a year with our two-year-old son in 1965-1966 was a crucial experience. I had joined my husband, who was employed in the Jebel Marra Project in Western Darfur (see 
G. Haaland, 1967). That year among the Fur people gave direction to my interpretative quest. I observed that there was a near equal workload between husbands and wives in cultivation activities. By being with the women in the village, I was struck that women were busy all the time. They were nurturing children, weeding, husking, winnowing, and grinding grain; they were also fetching water and cutting firewood, sweeping the hut and the compound, boiling porridge, and brewing beer (Figs. 11 \& 12). At 4-5 am, while still dark, I often woke up to the sound of sorghum grinding. This female activity went on for 2-3 hours before other tasks had to be undertaken. Grinding is an activity that gradually wears down the body. These daily chores seemed to be somehow taken as a natural condition of being a woman (by the Fur and anthropologists).

The year among the Fur women had a tremendous impact on me, but it took me a long time to realize the archaeological importance of insights that I had gained from hanging around with women in the villages. Later, this alerted me to see the close symbolic associations between female identity, nurturing, foodprovisioning, pottery-making, and food-pots. The Fur used the human body terms to describe parts of pots. They explicitly conceptualized pots as females associated with motherhood. However, drawing on such 'subjective' experiences to interpret archaeological materials was not considered 'scientific' when I started my archaeological career. It, therefore, took me some time to see the potential of systematically using ethnographic observations as an inspiration to make interpretations that could serve as provisional hypotheses about the socio-cultural context of prehistoric material.

$L V$ and MJ: You entered the archaeology of Sudan in the early 1970s, and soon after, you began to open topics that had not been addressed in the field before. In some of them, you remained for a long time the only source to cite. These include the role of women in cultural adaptations. Could you describe the trajectory of this theme and the way it developed over the decades?

$R H$ : I saw the importance of women in cultural history, especially in fundamental cultural changes such as the innovation of pottery and cultivation. The observation of women's daily activities made me realize the role of women in prehistoric cultural changes, including the gender implications of ceramic technology and cooking. Based on ethnographic material and archaeological evidence, I assumed that it was within the female sector of activities that the important innovation of applying fire to transform a natural item, clay, into a cultural product, the pot, took place. Pottery making and cooking involve activities that, in many respects, are similar, such as grinding, use of water, kneading, and firing. These general processes had wider implications, such as sedentism, population growth, and population expansion. Moreover, I underlined the female role in the transition towards sedentism. I realized that women would have benefitted the most from this change, especially due to pregnancy and responsibility for the children. Most of the previous studies focused on the importance of male hunters in the quest for food, as the symposium and the proceedings Man the Hunter organized by Richard Lee and Irven DeVore in 1966 and published in 1968 illustrate (Lee and DeVore, 1968).

I emphasized the role of women in breastfeeding and the innovation of pottery which was essential for feeding children and boiling food such as gruel and beer (Fig. 13). I discussed the consequences of pottery, such as increased sedentism, increase in population, and transition to agriculture (e.g., Haaland, 1995, 1997, 2006). Furthermore, I focused on mother's milk and the importance of beer as food for infants after weaning them from breastmilk (Haaland, 2021). Fermented food such as beer would have been sweet and easier to digest for children. During my stay among the Fur, I observed women feeding toddlers millet beer from an early age. This came as a surprise since I grew up in a rather puritan coastal community in Norway. It took me some time to realize the importance of beer as healthy food, which the Fur people referred to as liquid porridge (Fig. 14).

$L V$ and MJ: In your view, what is the state of gender studies in African archaeology?

$R H$ : My experience working with female students and archaeologists from Africa is their broad interest in gender and gender studies. They have a different cultural background from most archaeologists who have been working on this topic. Thus, they have the opportunity to pose new perspectives and questions. Importantly, with their knowledge of the local culture and language, they would have an advantage in their approach to the material. I want to mention Intisar Soghayroun Elzein from Sudan, focusing on gender in Medieval Islamic archaeology. She has been in 
Fig. 12 Fur women making beer, grinding millet for beer-making (in the background), and a woman stirring the big boiling pot (left in the foreground). Photo by Gunnar Haaland, 1973.

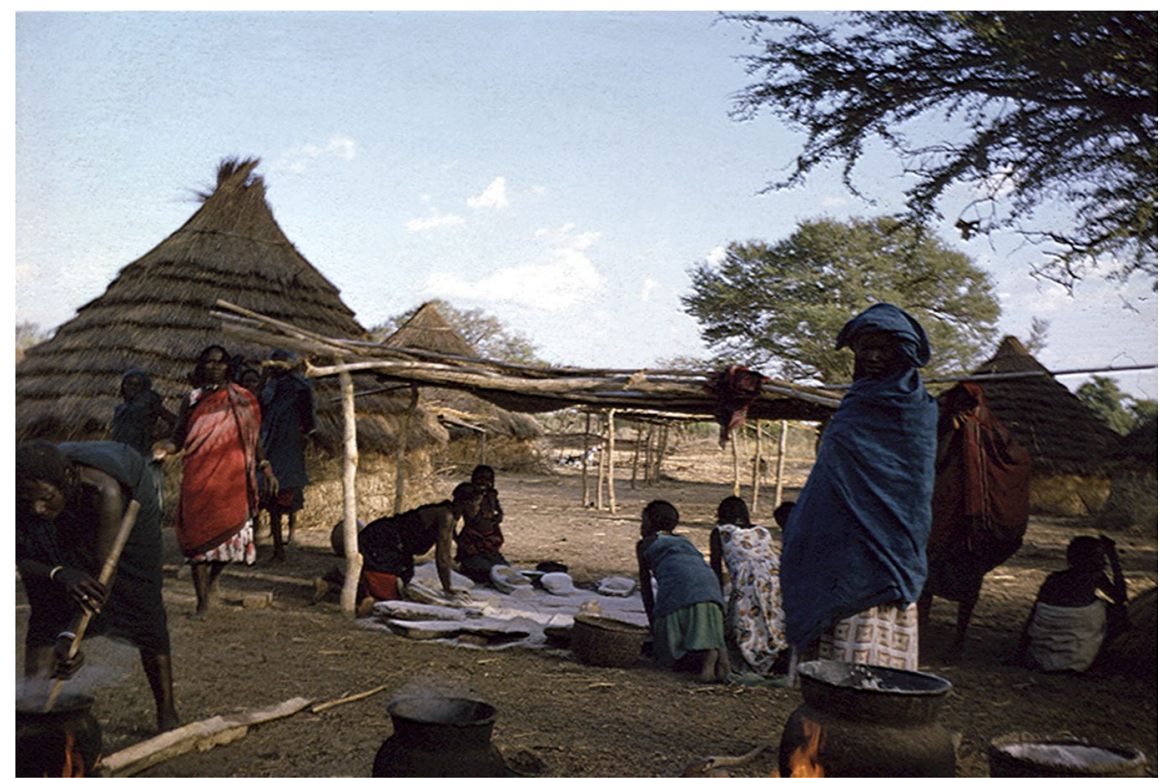

charge of a project excavating and recording material from the medieval village of El-Khandaq along the Nile in northern Sudan. Interestingly, she has been collecting information on the perspectives of the local women on work and material culture.

\section{Legacy}

$L V$ and MJ: Throughout your life, you have worked at several universities in Africa. How would you characterize archaeology at these institutions - in the past and at present?

$R H$ : In Khartoum, the Department of Archaeology was separated from the Department of History as early as 1971. This gave archaeology in Sudan a strong and independent status and made it easier to develop interdisciplinary contacts and cooperation with other disciplines, such as anthropology, botany, and zoology, located in other colleges (faculties). My experience as a lecturer was that students were highly motivated. After BA exams, the academically best qualified could enroll in the BA Honors degree. The BA Honors thesis was an independent piece of work of about 70-90 pages. The standard of the Honors thesis at the time was very high and compared well in quality and volume with the current master's thesis at the University of Bergen. It would take five years to complete an Honors degree.

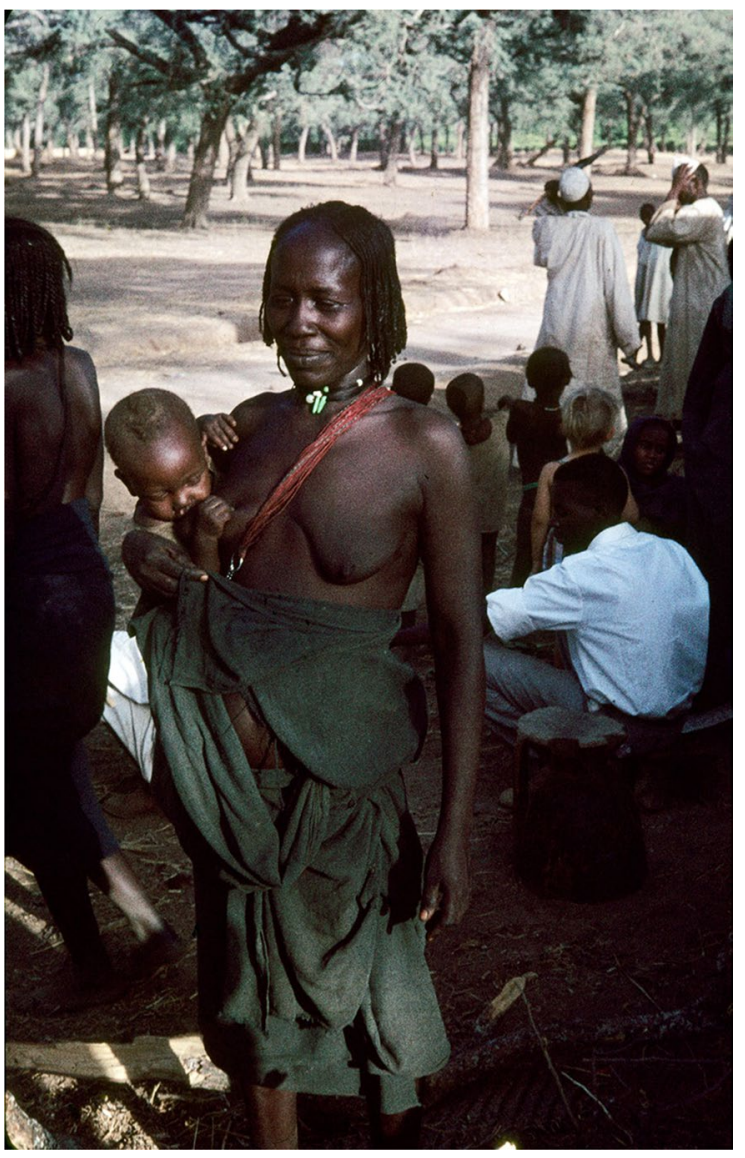

Fig. 13 Fur woman nursing her baby outside the village of Zalingei. Photo by Randi Haaland, 1973. 
During my decades of teaching in Africa, I have observed the rather limited academic contacts between African universities. The students often have limited knowledge about the cultural history and the archaeological projects in other African countries. I noticed this when I supervised at the same time a group of students from four African countries: Sudan, Ethiopia, Kenya, and Zimbabwe. It is important that African universities use the capacity of each other for training, collaborative research, and selecting external examiners. I think building strong south-south relationships and cultivating academic contacts between archaeologists in different African countries is just as desirable as implementing capacity-building programs and academic cooperation with European institutions. There are many challenges that archaeology in Africa faces in our times (e.g., Chirikure et al., 2021; Ogundiran, 2021), and the establishment of contacts and networks throughout the continent will provide a more solid ground on which to address these challenges. The contact is happening but at a limited scale - at regional levels (e.g., between universities in Nigeria and Ghana) or thanks to the initiatives of the Swedish Development Cooperation Agency, Department for Research Cooperation (SIDA/SAREC), and similar institutions (e.g., Chirikure et al., 2021). These efforts should be broadened. In this connection, I have also noticed that Sudanese archaeologists attend Nubia-related conferences more regularly than the
Society for Africanist Archaeologists (SAfA) and the PanAfrican Archaeological Association (PANAF) conferences. This has resulted in silo-effect and limited cross-cultural perspectives in Sudanese archaeology.

$L V$ and MJ: Many of the students you supervised later became excellent scholars focusing on diverse aspects of African archaeology. Who among them would you mention specifically, and why?

$R H$ : I am very happy and proud that all the 25 NORAD-NUFU-funded students I supervised for their master's degree and doctorate went back to their home countries to work at universities or museums. I see them as important contributors to the cultural history of their countries. Only two students from Palestine did not return to their countries. I was rather disappointed since they could have been important in giving a voice to the archaeology of Palestine, which has been heavily influenced by Israeli archaeologists. Nonetheless, I can understand their choice since the political situation has been and still is quite difficult. In addition to Palestine and Nepal, the students came from ten countries in Africa: Sudan, Ethiopia, Kenya, Tanzania, Botswana, Zimbabwe, Ghana, Uganda, Rwanda, and South Africa. It was a challenge to supervise students who had quite different cultural interests and academic backgrounds. However, it was also inspiring since it forced me to keep up with the topics other students worked on for their theses.
Fig. 14 Fur men drinking beer at a work party, building a house. Photo by Gunnar Haaland, 1973.

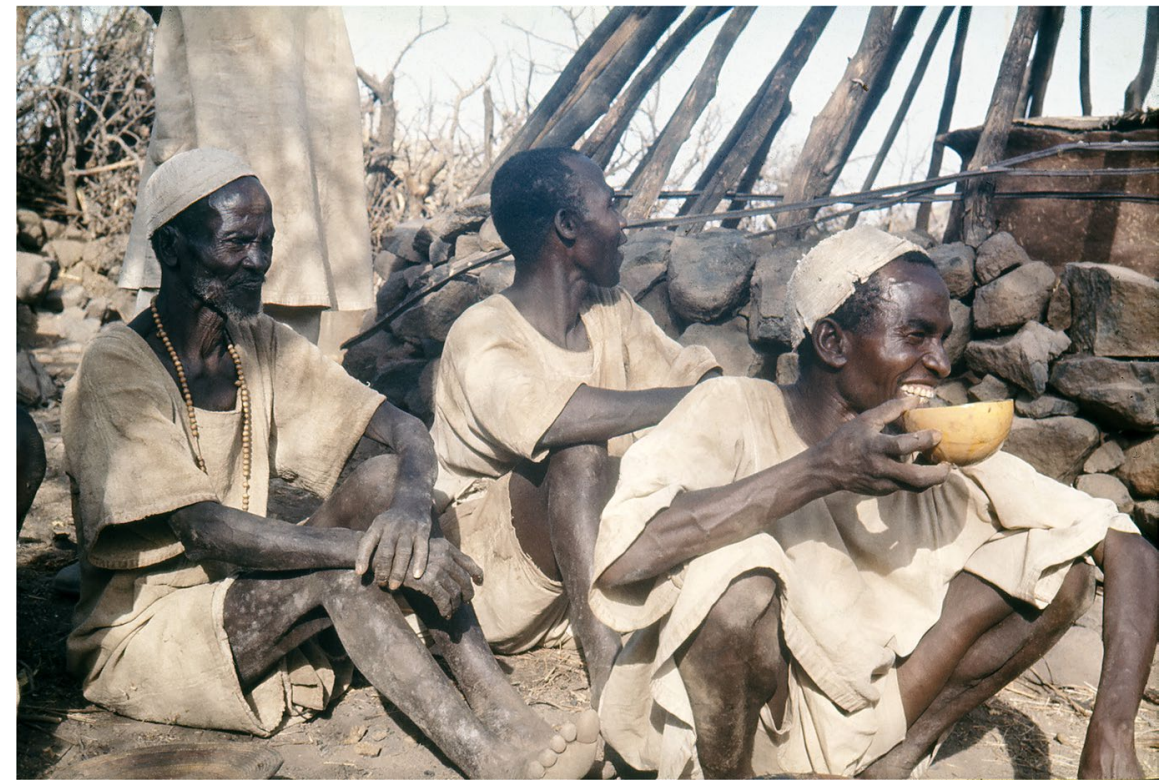


It gave me quite a wide knowledge of Africa. I will emphasize one student that stands out: Freda Nkirote M'Mbogori. A single mother, she did her master's degree with me in Bergen. During her two-year study (2004-2006), she brought her little son to Norway to experience the Norwegian culture and the snow and skiing. She later went on to Paris for her doctoral degree. After completing her degrees, she was the first female archaeologist and first African to become the director of the British Institute in Eastern Africa in Nairobi, and in 2018 she was elected the president of the Pan-African Archaeological Association.

$L V$ and $M J$ : What are you working on at this moment?

$R H$ : In my earlier work, I focused on the striking difference in the technology and symbolism of food between Africa and the Near East. I saw this difference as grounded in the contrast between a cooking pot theme in Africa and a baking oven theme in the Near East. I am now working on the importance of beer in the early weaning of infants. The invention of pottery was necessary for the development of boiled food culture and beer-making in Africa and may have played a role in weaning infants from breastfeeding in Neolithic Sudan. This contrasts with the Near East with a lack of pottery on the path towards the Neolithic. The significance of beer in the Near East has, to a large extent, been in the context of feasting. I want to investigate this contrast in a wider regional context which includes the Indian subcontinent. Here one finds the importance of the bread and oven complex in the western region, where it became important in the Indus Valley civilization. In contrast, the central-northern region established a pot and porridge cultural complex in many ways similar to the African system. I will try to investigate this contrast. Ultimately, I want to carry out further study on the populations of Nepalese hilly areas to focus on the rich symbolism attached to beer in ritual settings like marriage and childbirth.

Acknowledgements The authors thank Petr Košárek from the Czech Institute of Egyptology for formatting the archival photographs.

Funding The work on the interview was supported by the European Regional Development Fund project "Creativity and Adaptability as Conditions of the Success of Europe in an Interrelated World" (reg. no.: CZ.02.1.01/0.0/0.0/16_019/00 00734) (MJ) and by the Programme for the Development of
Fields of Study at Charles University, no. Q11: "Complexity and Resilience: Ancient Egyptian Civilization in Multidisciplinary and Multicultural Perspective" (LV).

\section{References}

Arkell, A. J. (1949). Early Khartoum. An account of the excavation of an early occupation site carried out by the Sudan Government Antiquities Service in 1944-5. Oxford University Press.

Barth, F. (1966). Models of social organization. Royal Anthropological Institute Occasional Papers 23. Royal Anthropological Institute.

Barth, F. (Ed.) (1969). Ethnic groups and boundaries: The social organization of culture difference. Universitetsforlaget.

Caneva, I. (Ed.) (1983). Pottery-using gatherers and hunters at Saggai (Sudan): Preconditions for food production. Università degli Studi "La Sapienza".

Chirikure, S., Ndoro, W., Bugarin, F. T., di Lernia, S., Ichumbaki, E. B., \& Lwoga, N. B. (2021). UNESCO and heritage tourism in Africa. African Archaeological Review, 38(3), 513533. https://doi.org/10.1007/s10437-021-09454-6

Clark, D. J. (1977). Comments on archaeological classification and ethnic groups. Norwegian Archaeological Review, 10(1-2), 18-20.

Close, A. E. (1995). Few and far between: Early ceramics in North Africa. In W. K. Barnett \& J. W. Hoopes (Eds.), The emergence of pottery. Technology and innovation in ancient societies (pp. 23-37). Smithsonian Institution Press.

Fuller, D. Q. (2007). Contrasting patterns in crop domestication and domestication rates: Recent archaeobotanical insights from the old world. Annals of Botany, 100(5), 903-924. https://doi.org/10.1093/aob/mcm048

Fuller, D. Q., Denham, T., Arroyo-Kalin, M., Lucas, L., Stevens, C. J., Qin, L., Allaby, R., \& Purugganan, M. D. (2014). Convergent evolution and parallelism in plant domestication revealed by an expanding archaeological record. Proceedings of the National Academy of Sciences, 111(17), 6147-6152. https://doi.org/10.1073/pnas.1308937110

Fuller, D. Q., Stevens, C., Lucas, L., Murphy, C., \& Qin, L. (2016). Entanglements and entrapments on the pathway toward domestication. In L. Der \& F. Fernandini (Eds.), The archaeology of entanglement (pp. 151-172). Left Coast Press.

Fuller, D. Q., Lucas, L., Carretero, G., \& Stevens, C. (2018). From intermediate economies to agriculture: Trends in wild food use, domestication and cultivation among early villages in Southwest Asia. Paléorient, 42, 59-74.

Garfinkel, Y. (1999). Neolithic and Chalcolithic pottery of the Southern Levant. Institute of Archaeology/Hebrew University Press.

Haaland, G. (1967). Methodological considerations. In F. Barth (Ed.), Human resources. Report submitted to FAO. Occasional Papers, No. 1. Department of Social Anthropology.

Haaland, G. (1990). Øl og morsmelk. Symbol, moral og valg i Fursamfunnet'. Norsk Antropologisk Tidsskrift, 1, 3-16.

Haaland, G. (1998). Beer, blood and mother's milk. Sudan Notes and Records, 2, 53-75. 
Haaland, R. (1977). Archaeological classification and ethnic groups: A case study from Sudanese Nubia. Norwegian Archaeological Review, 10, 1-18.

Haaland, R. (1995). Sedentism, cultivation and plant domestication in the Holocene Middle Nile Region. Journal of Field Archaeology, 22(2), 157-174.

Haaland, R. (1997). Emergence of sedentism: New ways of living, new ways of symbolizing. Antiquity, 71(272), 374-385.

Haaland, R. (1999). The puzzle of the late emergence of domesticated sorghum in the Nile Valley . In C. Gosden \& J. Hather (Eds.), Prehistory of food. Appetites for change (pp. 397-419). Routledge.

Haaland, R. (2006). Africa and the Near East: Pot and porridge, bread and oven - Two food systems maintained over 10,000 years. In H.-P. Wotzka (Ed.), Grundlegungen. Beiträge zur europäischen und afrikanischen Archäologie für Manfred K. H. Eggert (pp. 243-254). Francke.

Haaland, R. (2011). Crops and culture: Dispersal of African millets to the Indian subcontinent and its cultural consequences. Dhauglagiri Journal of Sociology and Anthropology, 5, 1-29.

Haaland, R. (2014a). Introduction. Africa and the Indian Ocean. African Archaeological Review, 31(4), 543-545.

Haaland, R. (2014b). The Meroitic Empire: Trade and cultural influences in an Indian Ocean context. African Archaeological Review, 31(4), 649-673.

Hodder, I. (1980). Interpretation of spatial variation in material culture: Some suggestions and hypotheses. In R. E. Leakey \& B. A. Ogot (Eds.), Proceedings of the 8th Panafrican Congress of Prehistory and Quaternary Studies, Nairobi, September 1977 (pp. 29-30). International Louis Leakey Memorial Institute for African Prehistory.

Hodder, I. (1982). Symbols in action: Ethnoarchaeological studies of material culture. Cambridge University Press.

Hofmann, I. (1975). Wege und Möglichkeiten eines indischen Einflusses auf die meroitische Kultur. Studia Instituti Anthropos 23. Anthropos-Institut.

Huysecom, E. (2020). The first emergence of ceramic production in Africa. In Oxford research encyclopedia of anthropology. Oxford University Press. https://doi.org/10.1093/ acrefore/9780190854584.013.66

Huysecom, E., Rasse, M., Lespez, L., Neumann, K., Fahmy, A., Ballouche, A., Ozainne, S., Maggetti, M., Tribolo, Ch., \& Soriano, S. (2009). The emergence of pottery in Africa during the tenth millennium cal BC: New evidence from Ounjougou (Mali). Antiquity, 83, 905-917.

Jesse, F. (2010). Early pottery in Northern Africa - An overview. Journal of African Archaeology, 8(2), 219-238. https://doi.org/10.3213/1612-1651-10171

Krzyżaniak, L., \& Kobusiewicz, M. (Eds.) (1984). Origin and early development of food-producing cultures in NorthEastern Africa. Studies in African Archaeology, vol. 1. Poznań Archaeological Museum.

Lee, R. B., \& DeVore, I. (Eds.) (1968). Man the hunter. The first intensive survey of a single, crucial stage of human development: Man's once universal hunting way of life. Aldine.

Lynn, C. D., Howells, M. E., \& Stein, M. J. (2018). Family and the field: Expectations of a field-based research career affect researcher family planning decisions. PLOS ONE,
13(9), e0203500. https://doi.org/10.1371/journal.pone. 0203500

Moore, A. M. T. (1995). The inception of potting in Western Asia and its impact on economy and society. In W. K. Barnett \& J. W. Hoopes (Eds.), The emergence of pottery (pp. 39-54). Smithsonian Institution Press.

Nordström, H.-А. (Ed.) (1972). Neolithic and A-Group sites. The Scandinavian Joint Expedition to Sudanese Nubia Publication, vol. 3. University Publishers.

Ogundiran, A. (2021). Doing archaeology in a turbulent time. African Archaeological Review, 38, 397-401. https://doi.org/10.1007/s10437-021-09460-8

Popper, K. (1972). Conjectures and refutations: The growth of scientific knowledge. Routledge \& K. Paul.

Sauer, C. O. (1952). Agricultural origins and dispersal. American Geographical Society.

Shinnie, P. L., \& Shinnie, M. (1978). Debeira West. A Mediaeval Nubian town. Aris \& Phillips Ltd.

Sohn, E. (2019). The family way. Nature, 570, 405-407.

Trigger, B. G. (1965). History and settlement in Lower Nubia. Yale University Publications in Anthropology, No. 69. Yale University Press.

Trigger, B. G. (1977). Comments on archaeological classification and ethnic groups. Norwegian Archaeological Review, 10(1-2), 20-23.

Trigger, B. G. (1989). History of archaeological thought. Cambridge University Press.

Wendorf, F. et al. (1968). The prehistory of Nubia, 2 vols. Southern Methodist University Press.

Wendorf, F., Marks, A. E., \& Shiner, J. L. (1977). Comments on archaeological classification and ethnic groups. Norwegian Archaeological Review, 10(1-2), 23-26.

Winchell, F., Brass, M., Manzo, A., Beldados, A., Perna, V., Murphy, C., Stevens, C., \& Fuller, D. Q. (2018). On the origins and dissemination of domesticated sorghum and pearl millet across Africa and into India: A view from the Butana Group of the Far Eastern Sudan. African Archaeological Review, 35, 483-505. https://doi.org/10.1007/ s10437-018-9314-2

\section{Randi Haaland: Selected Bibliography (in Chronological Order)}

Haaland, R. (1972). Lithic Material. In H.-Å. Nordström (Ed.) Neolithic and A-Group sites (pp. 95-116). The Scandinavian Joint Expedition to Sudanese Nubia Publication, vol. 3. University Publishers.

Haaland, R. (1977). Archaeological classification and ethnic groups: A case study from Sudanese Nubia. Norwegian Archaeological Review, 10, 1-18.

Haaland, R. (1978). Ethnographical observations of potterymaking in Darfur, Western Sudan, with some reflections on archaeological interpretations. In K. Kristiansen \& C. Paludan Müller (Eds.), New directions in Scandinavian archaeology (pp. 48-61). National Museum Publications.

Haaland, R. (1978). The seasonal interconnection between Zakiab and Kadero: Two Neolithic sites in Central Sudan. Nyame Akuma, 13, 31-35. 
Haaland, R. (1980). Lithic tools as possible indicators of early domestications. In R. E. Leakey \& B. A. Ogot (Eds.), Proceedings of the 8th Panafrican Congress of Prehistory and Quaternary Studies, Nairobi, September 1977 (pp. 265269). International Louis Leakey Memorial Institute for African Prehistory.

Haaland, R. (1980). Man's role in the changing habitat of Mema during the Old Kingdom of Ghana. Norwegian Archaeological Review, 13, 31-47.

Haaland, R. (1981). Migratory herdsmen and cultivating women. The structure of Neolithic seasonal adaptation in the Khartoum Nile environment. Ph.D. thesis. University of Bergen, Norway.

Haaland, R. (1981). Seasonality and division of labour: A case study from the Khartoum Nile environment. Norwegian Archaeological Review, 14, 44-59.

Haaland, R., \& Haaland, G. (1982). I begynnelsen: fra de forste mennesker til de forste sivilisasjoner. Aschehougs Verdenshistorie 1. [In the beginning: From the first humans to the first civilizations. Aschehoug's World History, Vol. 1]. H. Aschehoug \& Co.

Haaland, R. (1987). Socio-economic differentiation in the Neolithic Sudan. BAR International Series 350. Cambridge Monographs in African Archaeology, 20.

Haaland, R. (1988). The role of ethno-archaeology and experimental archaeology in the interpretation of prehistoric societies. In S. Indrelid, S. Kaland, \& B. Solberg (Eds.), Arkeologiske Skrifter No. 4 fra Historisk Museum (pp. 130-140). University of Bergen.

Haaland, R. (1989). On the use of archaeological and linguistic evidence in the socio-cultural evolution in prehistoric Sudan. In R. Skarstein, E. Kleppe, \& R. B. Finnestad (Eds.), Understanding and history in arts and sciences (pp. 127-144). Solum Forlag.

Haaland, R. (1992). Fish, pots and grain in early and mid-Holocene adaptations in the Central Sudan. African Archaeological Review, 10, 43-64.

Haaland, R. (1993). Aqualithic sites in the Middle Nile Region. Azania: Archaeological Research in Africa, 28(1), 47-86.

Haaland, R. (1994). Dakawa, an early Iron Age site in Tanzanian hinterland. Azania: Archaeological Research in Africa, 29-30, 238-247.

Haaland, R. (1995). Sedentism, cultivation and plant domestication in the Holocene Middle Nile Region. Journal of Field Archaeology, 22, 157-173.

Haaland, R., \& Haaland, G. (1995). Who speaks the Goddess's language? Imagination and method in archaeological research. Norwegian Archaeological Review, 28, $105-122$.

Haaland, R., \& Magid, A. A. (1995). Aqualithic sites along the Rivers Nile and Atbara, Sudan. Alma Mater Forlag.

Haaland, R. (1997). Emergence of sedentism: New ways of living, new ways of symbolizing. Antiquity, 71(272), 374-385.

Haaland, R. (1999). The puzzle of the late emergence of domesticated sorghum in the Nile Valley. In C. Gosden \& J. Hather (Eds.), Prehistory of food. Appetites for change (pp. 397-419). Routledge.
Haaland, R., \& Msuya, C. S. (2000). Pottery production, iron working, and trade in the Early Iron Age: The case of Dakawa, east-central Tanzania. Azania: Archaeological Research in Africa, 35, 75-106.

Haaland, R. (2002). Late Paleolithic technology among huntergatherers in the Dang valley 10-12,000 years ago. In R. P. Chaudhary, B. P. Subedi, O. R. Vetaas, \& T. H. Aase (Eds.), Vegetation and society: Their interaction in the Himalayas (pp. 201-209). Tribhuvan University.

Haaland, R., Haaland, G., \& Rijal, S. (2002). Social life of iron. A cross-cultural study of technological, symbolic and social aspects of iron making. Anthropos, 97, 35-54.

Haaland, R. (2004). Food, pots, and gender. In R. Barndon, S. Innselset, K. K. Kristoffersen, \& T. K. Lødøen (Eds.), Samfunn, symboler og identitet - Festskrift til Gro Mandt på 70-årsdagen (pp. 261-278). Arkeologisk institutt, Universitetet i Bergen.

Haaland, R. (2004). Technology, transformation, and symbolism: Ethnographic perspectives on European iron working. Norwegian Archaeological Review, 37, 1-19.

Haaland, R., \& Haaland G. (2004). The Ethiopian smelter and his world [56 minutes film]. Presented at the $17^{\text {th }}$ biennial meeting of the Society of Africanist Archaeologists, Bergen Norway, June 26 to 29, 2004, and at the Smithsonian Institute in Washington, April 2006.

Haaland, R., Haaland G. \& Dea, D. (2004). Smelting iron: Caste and its symbolism in southwestern Ethiopia. In T. Insoll (Ed.), Belief in the past (pp. 75-78). BAR International Series 1212.

Haaland, R. (2006). Africa and the Near East: Pot and porridge, bread and oven - Two food systems maintained over 10,000 years. In H.-P. Wotzka (Ed.), Grundlegungen. Beiträge zur europäischen und afrikanischen Archäologie für Manfred K. H. Eggert (pp. 243-254). Francke.

Haaland, R. (2007). Porridge and pot, bread and oven: Food ways and symbolism in Africa and the Near East. From the Neolithic to the present. Cambridge Archaeological Journal, 17(2), 167-183.

Haaland, R., \& Haaland, G. (2007). God of war, worldly ruler, and craft specialists in the Meroitic Kingdom: Inferring social identity from material remains. Journal of Social Archaeology, 7(3), 372-392.

Haaland, R., \& Haaland, G. (2008). Craft specialization, caste identities and political centralization. On the use of anthropological perspectives in reconstructing archaic forms of economic organization. In K. Chilidis, J. Lund, \& C. Prescott (Eds.), Facets of archaeology: Essays in honour of Lotte Hedeager on her 60th birthday (pp. 155168). Oslo arkeologiske serie, nr. 10. Unipub.

Haaland, R. (2011). Landscape. In T. Insoll (Ed.), Oxford handbook of archaeology and religion (pp. 24-37). Oxford University Press.

Haaland, R. (2012). Changing food ways as indicators of emerging complexity in Sudanese Nubia: From Neolithic agropastoralists to the Meroitic civilization. Azania: Archaeological Research in Africa, 47(3), 342-347.

Haaland, R. (2013). Iron working in an Indian Ocean context. In J. Humphris \& T. Rehren (Eds.), World of Iron (pp. 146-155). Archetype Books.

Haaland, R., \& Haaland, G. (2013). Early farming societies along the Nile. In P. L. Mitchell \& P. L. Lane (Eds.), 
Oxford handbook of African archaeology (pp. 545-552). Oxford University Press.

Haaland, R. (2014). Introduction. Africa and the Indian Ocean. African Archaeological Review, 31(4), 543-545.

Haaland, R. (2014). The Meroitic Empire: Trade and cultural influences in an Indian Ocean context. African Archaeological Review, 31(4), 649-673.

Haaland, R. (2017). The impact of women in cultural evolution. A personal reflection. Sudan \& Nubia, 21, 3-15.

Haaland, R., \& Haaland, G. (2017). Prehistoric figurines in Sudan. In T. Insoll (Ed.), Oxford handbook of prehistoric figurines (pp. 96-105). Oxford University Press.
Haaland, R. (2018). Cuisine and culture. Middle Asian and African culture defined. In A. Ekblom, C. Isendahl, \& K. J. Lindholm (Eds.), Resilience and heritage: Cultivating a future of the past. Essays in honour of Paul J. J. Sinclair (pp. 324-343). Uppsala University.

Haaland, R. (2021). Pottery, female identity, and beer in the Neolithic of Northern Africa: The importance of beer as boiled food for infants. Anthropologie, 59(3), 315-331.

Publisher's Note Springer Nature remains neutral with regard to jurisdictional claims in published maps and institutional affiliations. 